HORTSCIENCE 27(11):1196-1198. 1992.

\title{
Phytotoxicity of Bentazon to Woody and Herbaceous Landscape Plants
}

\author{
J.G. Norcini ${ }^{1}$ and J.H. Aldrich ${ }^{2}$ \\ University of Florida, Institute of Food and Agricultural Sciences, North \\ Florida Research and Education Center, Monticello, FL 32344 \\ Additional index words. Carissa macrocarpa, Hemerocallis, Juniperus horizontalis, \\ Liriope muscari, Ophiopogon japonicus, Pittosporum tobira, Raphiolepis indica, \\ Trachelospermum asiaticum, Basagran, postemergent herbicide
}

Abstract. Eight species of low-growing woody and herbaceous landscape plants were evaluated for tolerance to 1.1 or $2.2 \mathrm{~kg}$ a.i. bentazon/ha (plus a crop oil) applied over the top twice 7 days apart. Raphiolepis indica L. Lindl. 'Alba' was the only species tolerant to bentazon in either of two experiments. Bentazon injury to Liriope muscari (Decne.) L.H. Bailey 'Evergreen Giant' was minor (slight chlorosis) and would probably be tolerable under most landscape situations. Injury (primarily chlorosis/necrosis) to Carissa macrocarpa 'Emerald Blanket', Juniperus horizontalis Moench 'Bar Harbor', Pittosporum tobira (Thunb.) Ait. 'Compacta Green', Trachelospermum asiaticum (Siebold \& Zucc.) Nakai 'Aslo', Ophiopogon japonicus (Thunb.) Ker-Gawl., and Hemerocallis $\mathbf{x}$ 'Aztec Gold' was significant and therefore unacceptable. Chemical name used: 3-isopropyl-1H-2,1,3-benzothiadiazin-(4)-3H-one 2,2-dioxide (bentazon).

Postemergence control of yellow nutsedge (Cyperus esculentus L.) is a problem in landscape beds of the southeastern United States (Clewell, 1985; Melton et al., 1988). Bentazon is registered for postemergence control of yellow nutsedge and warm-season broadleaf weeds in and around woody and herbaceous landscape species. Yellow nutsedge control with bentazon is best achieved with $2.2 \mathrm{~kg}$ a.i./ha applied $\approx 1$ to 2 weeks apart (Derr and Appleton, 1989; Staller et al., 1975;

Received for publication 23 Dec. 1991. Accepted for publication 30 June 1992. This is Florida Agriculture Experiment Station no. R-02062. Funding was provided by the IR-4 Project. The cost of publishing this paper was defrayed in part by the payment of page charges. Under postal regulations, this paper therefore must be hereby marked advertisement solely to indicate this fact.

${ }^{1}$ Assistant Professor.

${ }^{2}$ Senior Biological Scientist.
William and Bendixen, 1987). This treatment will also control certain warm-season broadleaf weeds (Weed Science Soc. of America, 1983), including dichondra (Dichondra carolinensis Michx.) (personal observation).

Bentazon is usually applied as a directed spray away from the plant foliage, except for a few groundcover species. Only Liriope spicata Lour., L. muscari; Hedera helix L., Pachysandra terminalis Siebold \& Zucc., and Vinca minor L. are labeled as tolerant to topical applications. However, Derr and Appleton (1989) reported that $L$. muscari and $L$. muscari 'Variegata' were temporarily injured 20 days after a second bentazon application at 1.1 or $2.2 \mathrm{~kg}$ a.i./ha. While this injury might be tolerated in a production situation, it would be unacceptable in most landscape situations. Juniperus horizontalis 'Plumosa' and Cotoneaster dammeri Schneid. 'Royal Beauty' were severely injured by a 
Table 1. Injury to woody and herbaceous landscape species 7-35 days after repeat over-the-top applications of bentazon. ${ }^{\mathrm{z}}$ Bentazon was applied on 3 and 10 May (Expt. 1), or 14 and 21 June (Expt. 2).

\begin{tabular}{|c|c|c|c|c|c|c|c|}
\hline \multirow{4}{*}{$\begin{array}{l}\text { Species } \\
\text { and treatment }\end{array}$} & \multirow{4}{*}{$\begin{array}{c}\text { Ratc } \\
\left(\mathrm{kg} \cdot h \mathrm{a}^{-1}\right)\end{array}$} & \multicolumn{6}{|c|}{ Injury rating ${ }^{y}$} \\
\hline & & \multicolumn{3}{|c|}{ Expt. 1} & \multicolumn{3}{|c|}{ Expt. 2} \\
\hline & & \multicolumn{3}{|c|}{$\begin{array}{c}\text { Days after } 3 \text { May } \\
\text { application }\end{array}$} & \multicolumn{3}{|c|}{$\begin{array}{c}\text { Days after } 14 \text { June } \\
\text { application }\end{array}$} \\
\hline & & 7 & 14 & $\overline{35}$ & 7 & 14 & 35 \\
\hline \multicolumn{8}{|l|}{ Carissa } \\
\hline Water & $\cdots$ & 0 & 0 & 0 & 0 & 0 & 0 \\
\hline Water + crop oil & -.- & 0 & 0 & 0 & 0 & 0 & 0 \\
\hline Bentazon & 1.1 & 0 & 13 & 12 & 0 & 11 & 12 \\
\hline Bentazon & 2.2 & 0 & 46 & 20 & 0 & 28 & 20 \\
\hline LSD $5 \%$ & & NS & 8 & 4 & NS & 2 & 4 \\
\hline \multicolumn{8}{|l|}{ Hemerocallis } \\
\hline Water & --- & 0 & 0 & 0 & 0 & 0 & 0 \\
\hline Water + crop oil & --- & 0 & 0 & 0 & 0 & 0 & 0 \\
\hline Bentazon & 1.1 & 0 & 25 & 12 & 9 & 37 & 35 \\
\hline Bentazon & 2.2 & 0 & 50 & 17 & 17 & 51 & 41 \\
\hline LSD $5 \%$ & & NS & 8 & 3 & 10 & 8 & 4 \\
\hline \multicolumn{8}{|l|}{ Juniperus } \\
\hline Water &.-- & 0 & 0 & 0 & 0 & 0 & 0 \\
\hline Water + crop oil & --- & 0 & 0 & 0 & 0 & 0 & 0 \\
\hline Bentazon & 1.1 & 0 & 47 & 82 & 0 & 65 & 100 \\
\hline Bentazon & 2.2 & 0 & 60 & 99 & 10 & 86 & 100 \\
\hline LSD $5 \%$ & & NS & 3 & 6 & $<1$ & 5 & 0 \\
\hline \multicolumn{8}{|l|}{ Liriope } \\
\hline Water & -- & 0 & 0 & 0 & 0 & 0 & 0 \\
\hline Water + crop oil & -- & 0 & 0 & 0 & 0 & 0 & 0 \\
\hline Bentazon & 1.1 & 0 & 0 & 7 & 0 & 4 & 8 \\
\hline Bentazon & 2.2 & 0 & 0 & 9 & 10 & 10 & 10 \\
\hline LSD $5 \%$ & & NS & 0 & 3 & $<1$ & 3 & 3 \\
\hline \multicolumn{8}{|l|}{ Ophiopogon } \\
\hline Water & $\cdots$ & 0 & 0 & 0 & 0 & 0 & 0 \\
\hline Water + crop oil & --- & 0 & 0 & 0 & 0 & 0 & 0 \\
\hline Bentazon & 1.1 & 16 & 19 & 29 & 0 & 13 & 42 \\
\hline Bentazon & 2.2 & 17 & 40 & 45 & 10 & 34 & 63 \\
\hline LSD $5 \%$ & & 6 & 5 & 5 & 2 & 6 & 7 \\
\hline \multicolumn{8}{|l|}{ Pittosponum } \\
\hline Water & -- & 0 & 0 & 0 & 0 & 0 & 0 \\
\hline Water + crop oil & --- & 0 & 0 & 0 & 0 & 0 & 0 \\
\hline Bentazon & 1.1 & 0 & 21 & 52 & 0 & 3 & 55 \\
\hline Bentazon & 2.2 & 0 & 25 & 75 & 0 & 21 & 94 \\
\hline LSD $5 \%$ & & NS & 22 & 31 & NS & 12 & 18 \\
\hline \multicolumn{8}{|l|}{ Raphiolepis } \\
\hline Water &.-- & 0 & 0 & 0 & 0 & 0 & 0 \\
\hline Water + crop oil & --- & 0 & 0 & 0 & 0 & 0 & 0 \\
\hline Bentazon & 1.1 & 0 & 0 & 0 & 0 & 0 & 0 \\
\hline Bentazon & 2.2 & 0 & 0 & 0 & 0 & 0 & 0 \\
\hline LSD $5 \%$ & & & & & & & \\
\hline \multicolumn{8}{|l|}{ Trachelospermum } \\
\hline Water & $\cdots$ & 0 & 0 & 0 & 0 & 0 & 0 \\
\hline Water + crop oil & $\cdots$ & 0 & 0 & 0 & 0 & 0 & 0 \\
\hline Bentazon & 1.1 & 8 & 11 & 15 & 9 & 15 & 12 \\
\hline Bentazon & 2.2 & 19 & 40 & 35 & 12 & 27 & 38 \\
\hline LSD $5 \%$ & & 5 & 2 & 2 & 3 & 7 & 14 \\
\hline
\end{tabular}

${ }^{\mathrm{z}}$ All bentazon treatments contained a crop oil at 2.3 liters $\cdot \mathrm{ha}^{-1}$.

${ }^{\mathrm{y}}$ Injury rating scale of $0=$ no injury to $100=$ plant death, in increments of 10 . Injury was visually evaluated by two observers. The mean value is reported.

single application of bentazon at $0.84 \mathrm{~kg}$ a.i./ ha (Fretz and Sheppard, 1979). In contrast, Hemerocallis x 'Sammy Russell' and Hosta 'Hyacinthina' were tolerant of a single bentazon application at $1.1 \mathrm{~kg}$ a.i./ha (Melton et al., 1988).

The purpose of this study was to determine the safety of sequential over-the-top applications of bentazon at two rates to low-growing woody and herbaceous landscape species.

Rooted liners or divisions of Carissa ma- containing a medium composed of 3 pine bark : 1 Canadian sphagnum peat : 1 sand (by volume). One cubic meter of medium was amended with $6.1 \mathrm{~kg}$ dolomite, $3.1 \mathrm{~kg}$ superphosphate, $0.9 \mathrm{~kg}$ Micromax (12S-0.1B$0.5 \mathrm{Cu}-12 \mathrm{Fe}-2.5 \mathrm{Mn}-0.05 \mathrm{Mo}-12 \mathrm{Zn}$ ), and 6.1 $\mathrm{kg}$ Osmocote 18N-2.6P-1.0K (18-6-12); initial medium $\mathrm{pH}$ was 5.6. Half the plants of each species were treated between 0800 and $0900 \mathrm{HR}$ on 3 and 10 May (Expt. 1), and the other half on 14 and 21 June 1991 (Expt. 2), with bentazon applied over the top at 1.1 or $2.2 \mathrm{~kg}$ a.i./ha ( $1 \times$ and $2 \times$ rate for yellow nutsedge control, respectively). The bentazon solutions also contained a crop oil (Agri-Dex; $17 \%$ polyoxyethylated polyol fatty acid ester + polyol fatty acid ester, and $83 \%$ paraffin-based petroleum oil) at $2.3 \mathrm{li}$ ters $\cdot \mathrm{ha}^{-1}$. Control treatments were water with and without crop oil (2.3 liters.ha $\left.{ }^{-1}\right)$. Sprays were applied with a compressed-air backpack sprayer fitted with an 8004 flat fan nozzle set to deliver 467 liters $\cdot \mathrm{ha}^{-1}$. Conditions at the time of spraying were as follows: 3 May, air temperature $(\mathrm{AT})=17 \mathrm{C}$, relative humidity $(\mathrm{RH})=90 \%$; 10 May, $\mathrm{AT}=23 \mathrm{C}$, $\mathrm{RH}=93 \% ; 14$ June, $\mathrm{AT}=28 \mathrm{C}, \mathrm{RH}=$ $67 \% ; 21$ June, AT $=24 \mathrm{C}, \mathrm{RH}=94 \%$; wind speed on all dates was $<8 \mathrm{~km} \cdot \mathrm{h}^{-1}$. Height and width of the plants at the time of treatment for Expts. 1 and 2, respectively, were as follows: Carissa $(11 \times 6 \mathrm{~cm} ; 11$ $\times 25 \mathrm{~cm})$, Juniperus $(12 \times 17 \mathrm{~cm} ; 13 \times$ $25 \mathrm{~cm})$, Pittosporum $(11 \times 12 \mathrm{~cm} ; 17 \times$ $18 \mathrm{~cm})$, Raphiolepis $(10 \times 16 \mathrm{~cm} ; 19 \times 19$ $\mathrm{cm})$, Trachelospermum $(7 \times 28 \mathrm{~cm} ; 15 \times$ $40 \mathrm{~cm})$, Ophiopogon $(7 \times 17 \mathrm{~cm} ; 10 \times 20$ $\mathrm{cm})$, Liriope $(25 \times 22 \mathrm{~cm} ; 28 \times 25 \mathrm{~cm})$, and Hemerocallis $(25 \times 22 \mathrm{~cm} ; 45 \times 36$ $\mathrm{cm})$. All treated plants were placed in an open-sided rain shelter (30\% shade) for $6 \mathrm{~h}$, then hand-watered (to avoid wash-off) and placed on a full sun bed or in a shadehouse (30\% shade; Liriope, Hemerocallis, and Ophiopogon only). Overhead irrigation commenced the following day. Foliar phytotoxicity was evaluated independently by both authors on a scale where $0=$ no injury, $100=$ plant death in increments of 10,7 , $14,21,28$, and 35 days after the initial application in each experiment (results not shown for 21 and 28 days).

The experiment was a completely randomized design within a species, with five single-pot replications per treatment. Data were subjected to analysis of variance, with mean separation by least significant difference $(\alpha=0.05)$.

Raphiolepis was the only species tolerant to two bentazon treatments (1.1 and $2.2 \mathrm{~kg}$ a.i./ha; $1 \times$ and $2 \times$ rates, respectively) applied over the top 7 days apart (Table 1). No foliar injury or visible reduction in growth occurred. The crop oil caused no injury to any species (Table 1), but it may have enhanced bentazon injury on some. Derr and Appleton (1989) reported that the same crop oil increased bentazon injury on some azalea cultivars (Rhododendron $\times$ 'Hershey's Red' and 'Girard's Rose').

Bentazon caused varying degrees of injury to the other species 7 to 14 days after the 
initial application, with maximum injury generally occurring $\approx 14$ days after the second application (Table 1). Injury on most species occurred as a leaf-tip chlorosis that eventually spread over the remainder of the leaf and usually became necrotic. However, on Carissa, bentazon primarily stunted growth, with only a minor level of foliar chlorosis/necrosis. Phytotoxicity was ratedependent and appeared to be influenced by temperature. Under the higher temperatures in Expt. 2 (average minimum and maximum temperatures from 14 to 28 June were $\approx 3 \mathrm{C}$ higher than from 3 to 17 May), injury occurred sooner and/or was more severe except on Carissa and Trachelospermum.

Bentazon slightly injured Liriope, and new growth was unaffected. Derr and Appleton (1989) reported similar results for L. muscari. The minor degree of chlorosis on Liriope did not become necrotic, and it was frequently hard to detect without untreated plants for comparison. For these reasons, the use of bentazon in plantings of L. muscari 'Evergreen Giant' would probably be an acceptable means of yellow nutsedge control if temporary injury could be tolerated.

Bentazon caused unacceptable injury to the foliage of Hemerocallis x 'Aztec Gold' (Table 1). Injured plants had many more dead and dying leaves than untreated plants, which typically have a few dead leaves on the perimeter. Further, the affected leaves eventually abscised, resulting in visibly smaller plants than for untreated plants, although the appearance of bentazon-treated plants improved once the dead leaves had abscised. In contrast, Melton et al. (1988) reported that bentazon at $1.1 \mathrm{~kg}$ a.i./ha did not damage mature Hemerocallis x 'Sammy Russell'. Lack of injury may have been due to differences in cultivar tolerance or temperature. Hemerocallis x 'Sammy Russell' was exposed to temperatures $\approx 3 \mathrm{C}$ lower than 'Aztec Gold', and bentazon injury on 'Aztec Gold' occurred earlier under higher temperatures.

Juniperus was the most susceptible species to bentazon. Plants died at both rates in Expt. 2 and frequently at $2.2 \mathrm{~kg}$ a.i./ha in Expt. 1.

In conclusion, $R$. indica 'Alba' was the only woody or herbaceous landscape species in this study that was tolerant of sequential over-the-top applications of bentazon used for yellow nutsedge control. The minor chlorosis noted on L. muscari 'Evergreen Giant' would probably be tolerable in most landscape situations if bentazon provided significant cost savings compared with manual removal of yellow nutsedge. However, bentazon applications resulted in an injury level considered unacceptable for landscape plantings of Hemerocallis x 'Aztec Gold', C. macrocarpa 'Emerald Blanket', O. japonicus, $P$. tobira 'Compacta Green', T. asiaticum 'Aslo', and J. horizontalis 'Bar Harbor'.

\section{Literature Cited}

Clewell, A.F. 1985. Guide to the vascular plants of the Florida panhandle. Univ. Presses of Florida, Gainesville.
Derr, J.F. and B.L. Appleton. 1989. Phytotoxicity and yellow nutsedge control in azalea and liriope with Basagran (bentazon). J. Environ. Hort. 7:91-94.

Fretz, T.A. and W.J. Sheppard. 1979. Evaluation of bentazon for yellow nutsedge control in container-grown nursery stock. HortScience 14:71.

Melton, R., J. Kelly, and T. Whitwell. 1988. Use of Basagran for yellow nutsedge control in herbaceous perennials. Proc. Southern Nuerserymen's Assn. Res. Conf. 33:31-32.
Stoller, E.W., L.M. Wax, and R.L. Matthiesen. 1975. Response of yellow nutsedge and soybeans to bentazon, glyphosate and perfluidone. Weed Sci. 23:215-221.

Weed Science Society of America. 1983. Herbicide handbook of the Weed Science Society of America. 5th cd. Champaign, Ill. p. 50-54.

William, R.D. and L.E. Bendixen. 1987. Year round management of yellow nutsedge (Cyperus esculentus): An extension worker's summary. Weed Technol. 1:99-100. 